\title{
Amorphization of CuZr based alloy powders by mechanical milling
}

\author{
K. Tomolya ${ }^{1, a^{*}}$, D. Janovszky ${ }^{1, b}$, A. Sycheva ${ }^{1, c}$ \\ ${ }^{1}$ MTA-ME Materials Science Research Group, Miskolc-Egyetemvaros, Hungary

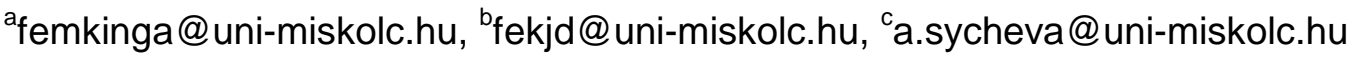

Keywords: amorphous/crystalline composite, powder, ball-milling, amorphization

\begin{abstract}
The effect of nickel addition was studied in the CuZr system creating alloys with near eutectic composition. Nickel and aluminum have been regarded as useful elements to improve the plasticity, thermal stability of the CuZr-based amorphous alloys. $\mathrm{Cu}_{49} \mathrm{Zr}_{45} \mathrm{Al}_{6}$ and $\left(\mathrm{Cu}_{49} \mathrm{Zr}_{45} \mathrm{Al}_{6}\right)_{95} \mathrm{Ni}_{5}$ were selected because of the good glass-forming ability. After $15 \mathrm{~h}$ of milling the structure of the powders was amorphous based on the XRD analysis. By adding nickel, the crystallization temperature $\left(\mathrm{T}_{\mathrm{x}}\right)$ shifted to higher temperatures compared to $\mathrm{CuZrAl}$ alloy. The value of supercooled liquid region was $64 \mathrm{~K}$, which means $\mathrm{CuZrAl}$ has a comparatively high glass forming ability.
\end{abstract}

\section{Introduction}

$\mathrm{Up}$ to date, ternary $\mathrm{Cu}-\mathrm{Zr}-\mathrm{Al}$ and quaternary $\mathrm{Cu}-\mathrm{Zr}-\mathrm{Al}-\mathrm{Ni}$ systems have been widely investigated by researchers because of their high glass forming ability and distinguished properties [1-3]. Aluminum and nickel have been regarded as useful elements to improve the plasticity, thermals stability and glass forming ability of the CuZr-based BMGs $[4,5,6]$.

Glassy alloys can be produced by casting and by solid state techniques such as mechanical alloying (MA) [7-10, 11] or mechanical milling (MM) [8, 12-13]. Both solid state techniques have now been shown to be capable of synthesizing a variety of equilibrium and non-equilibrium alloy phases starting from blended elemental or pre-alloyed powders. Additionally, powders can be mechanically activated to cause chemical reactions at near to room temperature, which is normally required to produce pure metals, nanocomposites, and a variety of commercially useful materials. The non-equilibrium phases synthesized include supersaturated solid solutions, metastable crystalline and quasicrystalline phases, nanostructures, and amorphous alloys. The advantage of MM over MA is that only reduction in particle size and transformation in the structure need to be induced mechanically since the powders are already alloyed, so the time required for processing is short. During milling, the effect of transmitted mechanical energy causes the formation of amorphous structure in the initial, crystalline powders. In a planetary ball-mill, both the vials and the support disk rotate around their own axes. Due to the centrifugal force produced by these rotations, the grinding balls hit each other and the wall of the vial while some amount of powder is trapped in between them [9]. Coalescence and fragmentation of the particles keep balance, because of the high mechanical stress effects caused by the balls. Repeated mechanical mixing, cold welding and fracturing take place and cause the formation of a fine powder with a changed structure. During the process, crystal defects e.g. dislocations, stacking faults and twin faults are introduced [14-15] and enhance disordering in the solid state. This disordering may finally cause solid-state amorphization. The production of BMG composites via powder consolidation has the advantage that the reinforcing particles can be distributed more easily.

Accordingly, in this work crystalline $\mathrm{Cu}_{49} \mathrm{Zr}_{45} \mathrm{Al}_{6}$ and $\left(\mathrm{Cu}_{49} \mathrm{Zr}_{45} \mathrm{Al}_{6}\right)_{95} \mathrm{Ni}_{5}$ alloys were ball-milled. $\mathrm{We}$ are going to report the microstructure evolution during mechanical milling. The effect of Ni on the glass forming range was investigated. 


\section{Experimental}

Master alloy ingots with the compositions of $\mathrm{Cu}_{49} \mathrm{Zr}_{45} \mathrm{Al}_{6}$ and $\left(\mathrm{Cu}_{49} \mathrm{Zr}_{45} \mathrm{Al}_{6}\right)_{95} \mathrm{Ni}_{5}$ were prepared by arc melting the mixtures of $\mathrm{Cu}, \mathrm{Zr}$, $\mathrm{Al}$ pure metals (min. 99.99\%) under purified argon atmosphere. These compositions were selected because of the good glass-forming ability. The master alloys were grinded and fractioned to a particle size below $300 \mu \mathrm{m}$ for ball-milling. The mechanical milling was performed in a Pulverisette 5 high-energy ball-mill in argon atmosphere using stainless steel vial and balls with a diameter of 5, 7 and $10 \mathrm{~mm}$ [16]. The overall process lasted $25 \mathrm{~h}$. The milling process was interrupted every hour. Each interruption was followed by a period of 2 hours to cool down the vials. The milled powder samples were extracted every 5 hours in order to examine the progress of amorphization reaction.

In order to expose the microstructure, both the master alloys and the powders were embedded in acrylic resin, then polished and etched with $0.5 \%$ hydrofluoric acid for $5 \mathrm{sec}$. The structure of both master alloy ingots and both powders was investigated by a Hitachi S4800 Field Emission Scanning Electron Microscope (SEM) equipped with a Bruker AXS Energy-dispersive X-ray Spectrometer (EDAX) system, a FEI Technai $\mathrm{G}^{2}$ Transmission Electron Microscope (TEM) and a Philips PW 1830 X-ray diffractometer (XRD) with monochromatized $\mathrm{CuK} \alpha$ radiation with a wavelength of $0.15418 \mathrm{~nm}$ using an anode voltage of $40 \mathrm{kV}$ and a current of $305 \mathrm{~mA}$. Amorphous fraction was determined by evaluation of XRD patterns. Using a combination of free software named Fityk 0.98 and software developed by us and called GerKiDo, different curves can be fitted to selected measuring points. The amorphous fraction can be calculated after measuring the area under the curves. Details are shown in Ref. 17. Thermal analysis was performed by a Netzsch 204 Differential Scanning Calorimeter (DSC) with a heating rate of $0.67 \mathrm{~K} / \mathrm{s}$.

\section{Results and discussion}

Based on the SEM analysis, results of EDAX and TEM, the formed phases in the master alloys

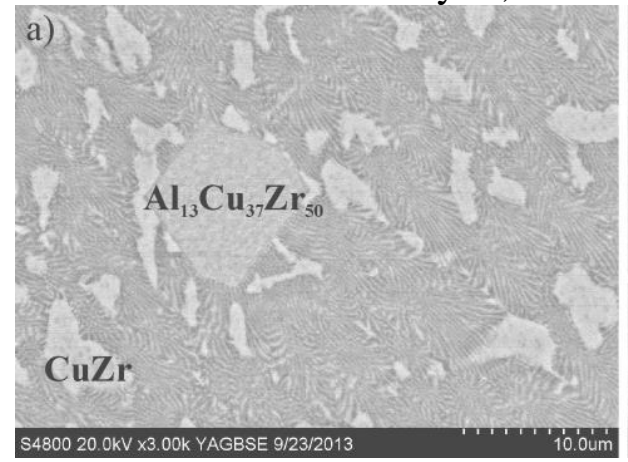

Fig. 1 SEM images of the master alloys a) $\mathrm{Cu}_{49} \mathrm{Zr}_{45} \mathrm{Al}_{6}$ b)

$$
\left(\mathrm{Cu}_{49} \mathrm{Zr}_{45} \mathrm{Al}_{6}\right)_{95} \mathrm{Ni}_{5}
$$

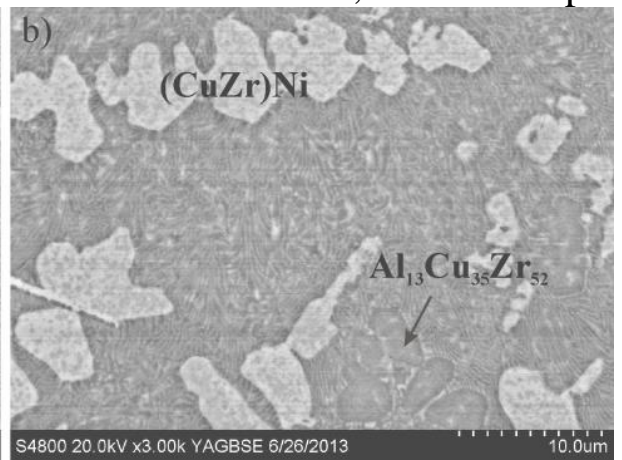

have been identified. Observing the microstructures of the master alloys in Fig. 1, it can be seen that an unknown phase with a composition of $\mathrm{Al}_{13} \mathrm{Cu}_{37} \mathrm{Zr}_{50} \quad$ (at \%) formed in both alloys, which has a distorted cubic unit cell with $a_{0}$ $=12,18 \AA, \gamma=90^{\circ}$.

Identified $\mathrm{CuZr}$ phase can be observed in $\mathrm{Cu}_{49} \mathrm{Zr}_{45} \mathrm{Al}_{6}$, which was found in the $\mathrm{Ni}$ containing alloy, as well. In this case, the $\mathrm{CuZr}$ dissolved 6 at\% nickel.

Furthermore, fine eutectic microstructure can be seen in both alloys. Fig. 2 displays TEM bright-field images of the $\mathrm{Cu}_{49} \mathrm{Zr}_{45} \mathrm{Al}_{6}$ alloy. $\mathrm{CuZr}$ and $\mathrm{AlCu}_{2} \mathrm{Zr}$ form the eutectic. $\mathrm{CuZr}$ has a
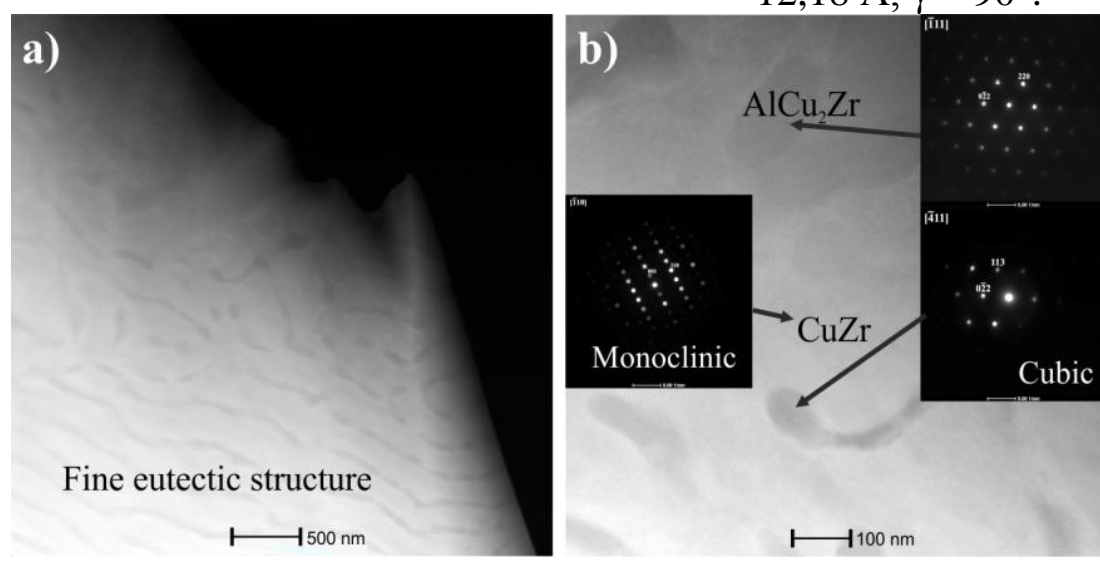

Fig. 2 TEM bright-field images of the $\mathrm{Cu}_{49} \mathrm{Zr}_{45} \mathrm{Al}_{6}$ alloy with corresponding electron diffraction patterns 
monoclinic unit cell with $\mathrm{a}_{0}=3.4 \AA, \mathrm{b}_{0}=4.3 \AA, \mathrm{c}_{0}=5.6 \AA, \beta=105^{\circ}$ (corresponding to Ref. 18) and $\mathrm{AlCu}_{2} \mathrm{Zr}$ has a face-centered cubic cell with $\mathrm{a}_{0}=6.2 \AA$ (corresponding to Ref. 19), respectively. The phase evolution of powders occurred during ball-milling was investigated as function of milling time, which can be seen in Fig. 3 and Fig. 4. For all the samples studied in this work, 25 hours were selected as maximal milling time. This time was chosen based on the results of our previous research [16], which is sufficiently long to reach a structure transformation, but short enough to avoid the impurities from the milling balls and vial.

The diffraction peaks attributed to the crystalline phases considerably reduced with increasing milling time. After $5 \mathrm{~h}$ of milling, 85 vol.\% of the structure transformed to amorphous and after 15 $\mathrm{h}$ of milling the peaks disappeared and only a broad diffuse halo remained indicating full amorphization in both cases. After that the recycling behavior of the amorphization progress by ball-milling was confirmed because new peaks belonging to new crystalline phases $(\mathrm{CuZr})$ appeared and their intensity increased slightly by further milling.

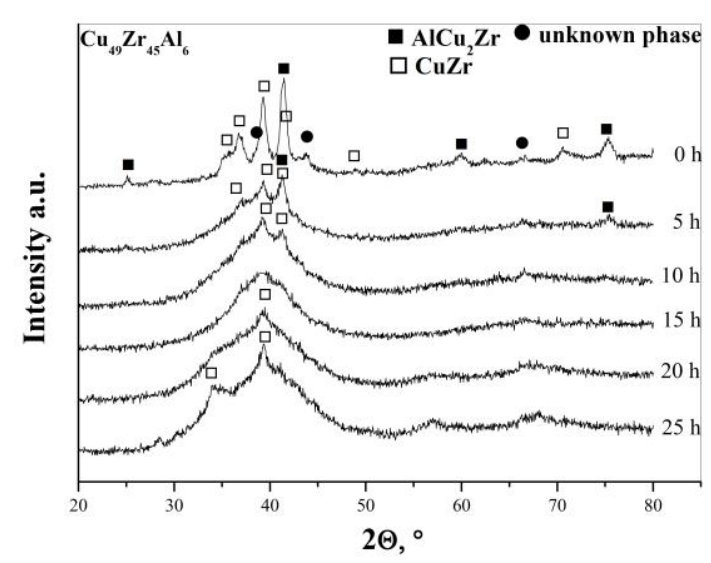

Fig. $3 \mathrm{XRD}$ patterns of the $\mathrm{Cu}_{49} \mathrm{Zr}_{45} \mathrm{Al}_{6}$ as-milled powders

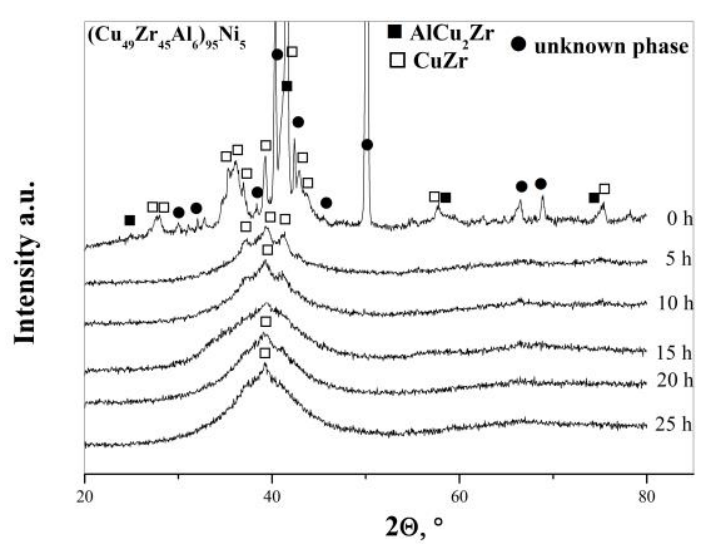

Fig. 4 XRD patterns of the $\left(\mathrm{Cu}_{49} \mathrm{Zr}_{45} \mathrm{Al}_{6}\right)_{95} \mathrm{Ni}_{5}$ as-milled powders

Fig. 5 and Fig. 6 display constant-rate heating DSC scans of the powders in the temperature range from 500 to $870 \mathrm{~K}$. A typical DSC curve of an amorphous alloy exhibits an endothermic event characteristic of the glass transition $\left(\mathrm{T}_{\mathrm{g}}\right)$ and a distinct undercooled liquid region, followed by one or two exothermic events corresponding to crystallization processes. According to the XRD pattern, the amorphization progressing in the first 15 hours appears to be confirmed, because the peaks become sharper up to 15 hours of milling, particularly in the Ni containing alloy. Peak temperatures of the as-milled powders are summarized in Fig. 7.

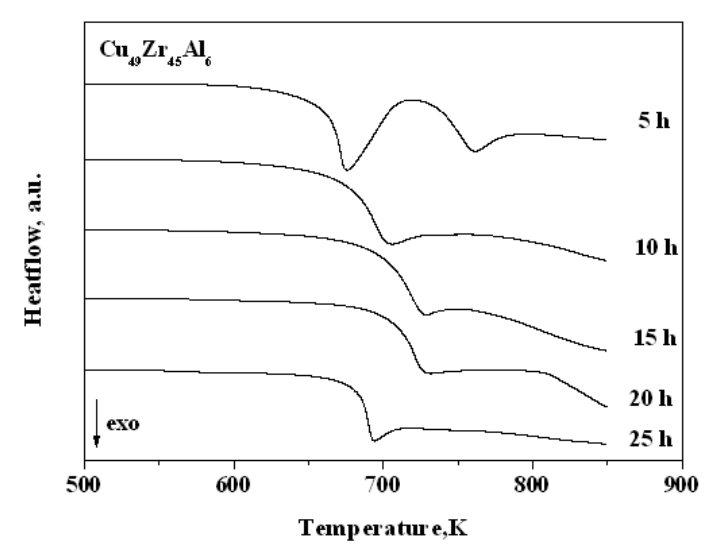

Fig. 5 DSC scans of the $\mathrm{Cu}_{49} \mathrm{Zr}_{45} \mathrm{Al}_{6}$ as-milled powders

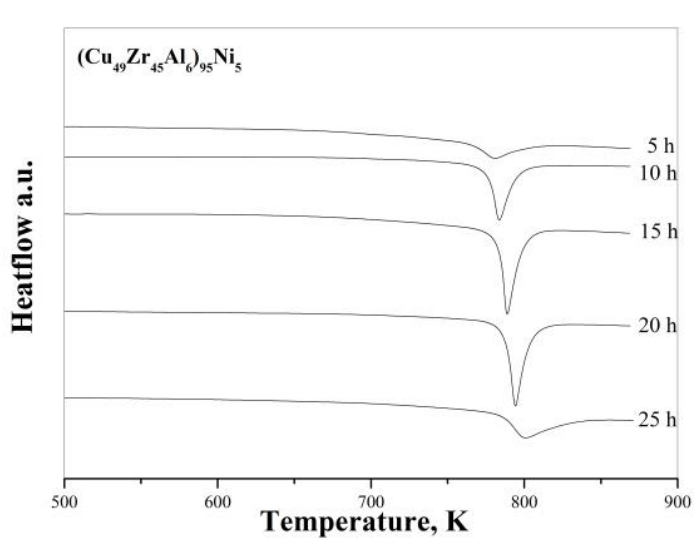

Fig. 6 DSC scans of the $\left(\mathrm{Cu}_{49} \mathrm{Zr}_{45} \mathrm{Al}_{6}\right)_{95} \mathrm{Ni}_{5}$ as-milled powders 
Polynomial curves are fitted to the $\mathrm{T}_{\mathrm{p}}$ temperature points of $\mathrm{Cu}_{49} \mathrm{Zr}_{45} \mathrm{Al}_{6}$. According to this function, during the first 15 hours of milling the peak temperatures shifted towards higher values and after that towards lower values. Other compositions in the $\mathrm{CuZrAl}$ system [20] behave similarly, but by adding $\mathrm{Ni}$ the tendency changed and the peak temperature increased monotonically with the milling time, the fitted curve is practically linear. As a result of nickel addition, the characteristics temperatures shifted to higher temperatures. Glass-forming ability has been evaluated by $\Delta \mathrm{T}_{\mathrm{x}}$ value, because large $\Delta \mathrm{T}_{\mathrm{x}}$ value implies high resistance against crystallization [18]. Table 1 summarizes thermal properties of the powders milled for $15 \mathrm{~h}$. Glass transition temperature can be seen only in the curve of $\mathrm{Cu}_{49} \mathrm{Zr}_{45} \mathrm{Al}_{6}$. The value of $\Delta \mathrm{T}_{\mathrm{x}}$ being equal to 64 implies a comparatively high glass forming ability. $\Delta \mathrm{H}$ is the crystallization enthalpy of the pure amorphous alloy, which is determined via measuring the exothermal peak of the DSC curve of partially crystallized alloy. The nickel addition enhanced the value of $\Delta H$.

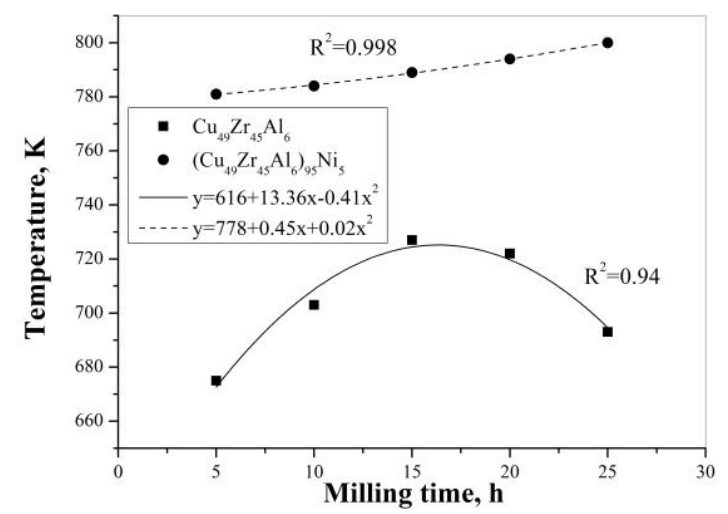

Fig. 7 Peak temperatures as function of milling time
Table 1 Thermal properties of amorphous powders milled for $15 \mathrm{~h}$

\begin{tabular}{|l|c|c|}
\hline & $\mathrm{Cu}_{49} \mathrm{Zr}_{45} \mathrm{Al}_{6}$ & $\left(\mathrm{Cu}_{49} \mathrm{Zr}_{45} \mathrm{Al}_{6}\right)_{95} \mathrm{Ni}_{5}$ \\
\hline $\mathrm{T}_{\mathrm{g}}, \mathrm{K}$ & 722 & 721 \\
\hline $\mathrm{T}_{\mathrm{x}}, \mathrm{K}$ & 786 & 779 \\
\hline$\Delta \mathrm{T}$ & 64 & 58 \\
\hline $\mathrm{T}_{\mathrm{p}}, \mathrm{K}$ & 727 & 789 \\
\hline$\Delta \mathrm{H}, \mathrm{J} / \mathrm{g}$ & 21 & 40 \\
\hline
\end{tabular}

The structure of the milled powders shows a mixture of the initial phases at an early stage of milling (Fig. 8b and 8f). It can be observed a lot of cracks in the particles owing to the mechanical stress. The original phase boundaries disappeared and the phases were undistinguishable at the end of milling (Fig. 8c-d and 8g-h). The structure of the powder at the end of the milling looks homogeneous in the case of non-etched samples. But after etching a very fine (below 1 micron) phase mixture can be observed. Coagulation and fragmentation is achieved during milling, which leads to the formation of cavities, pores and microcracks in the particles.
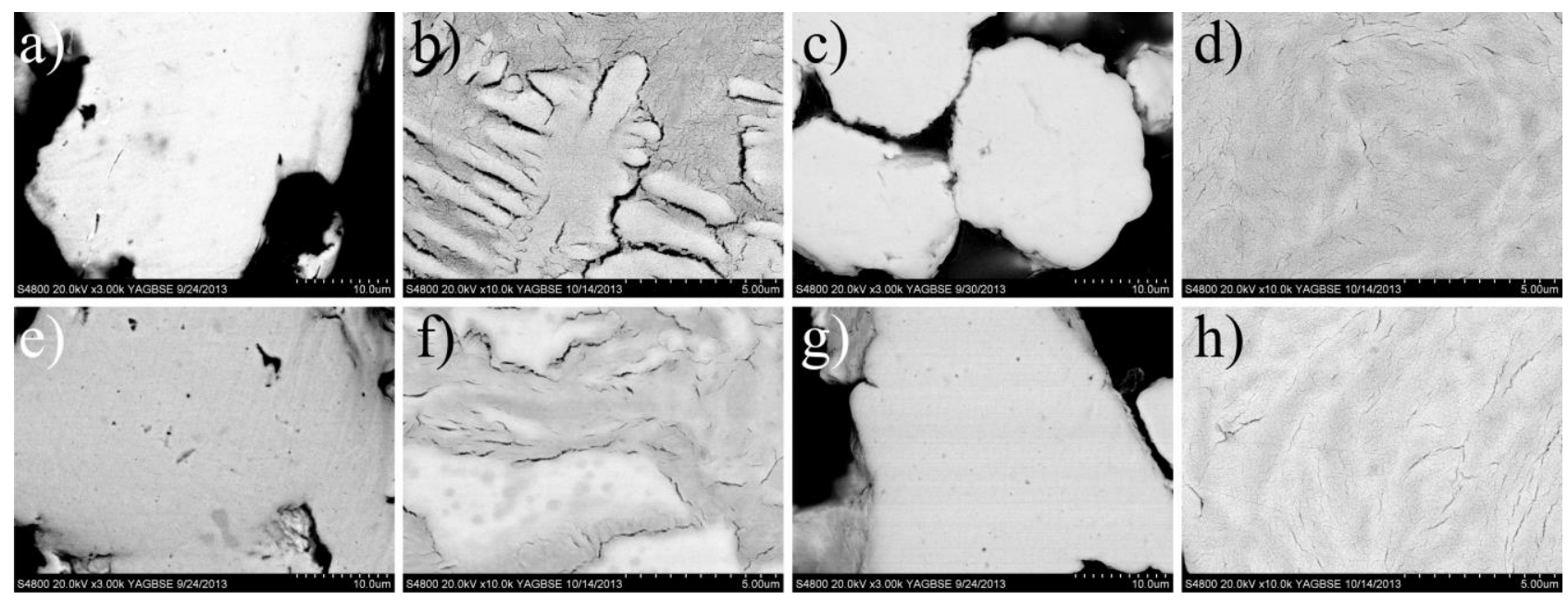

Fig. 8 SEM images of the milled powders a) $\mathrm{Cu}_{49} \mathrm{Zr}_{45} \mathrm{Al}_{6}$ after $5 \mathrm{~h}$ of milling, polished $\mathrm{b}$ )

$\mathrm{Cu}_{49} \mathrm{Zr}_{45} \mathrm{Al}_{6}$ after $5 \mathrm{~h}$ of milling, polished and etched c) $\mathrm{Cu}_{49} \mathrm{Zr}_{45} \mathrm{Al}_{6}$ after $15 \mathrm{~h}$ of milling, polished d)

$\mathrm{Cu}_{49} \mathrm{Zr}_{45} \mathrm{Al}_{6}$ after $15 \mathrm{~h}$ of milling, polished end etched e) $\left(\mathrm{Cu}_{49} \mathrm{Zr}_{45} \mathrm{Al}_{6}\right)_{95} \mathrm{Ni}_{5}$ after $5 \mathrm{~h}$ of milling, polished f) $\left(\mathrm{Cu}_{49} \mathrm{Zr}_{45} \mathrm{Al}_{6}\right)_{95} \mathrm{Ni}_{5}$ after $5 \mathrm{~h}$ of milling, polished and etched $\left.\mathrm{g}\right)\left(\mathrm{Cu}_{49} \mathrm{Zr}_{45} \mathrm{Al}_{6}\right)_{95} \mathrm{Ni}_{5}$ after

$15 \mathrm{~h}$ of milling, polished $\mathrm{h})\left(\mathrm{Cu}_{4} \mathrm{Zr}_{45} \mathrm{Al}_{6}\right)_{95} \mathrm{Ni}_{5}$ after $15 \mathrm{~h}$ of milling, polished and etched 
Based on the TEM investigation in Fig. 9, there are some crystalline phases sized from a few nanometres to ten nanometres in the amorphous matrix after $15 \mathrm{~h}$ milling. The electron diffraction pattern acquired from the matrix shows diffuse rings and discrete reflections (Fig. 9b), which proves the presence of amorphous and also nanocrystalline parts in the matrix.
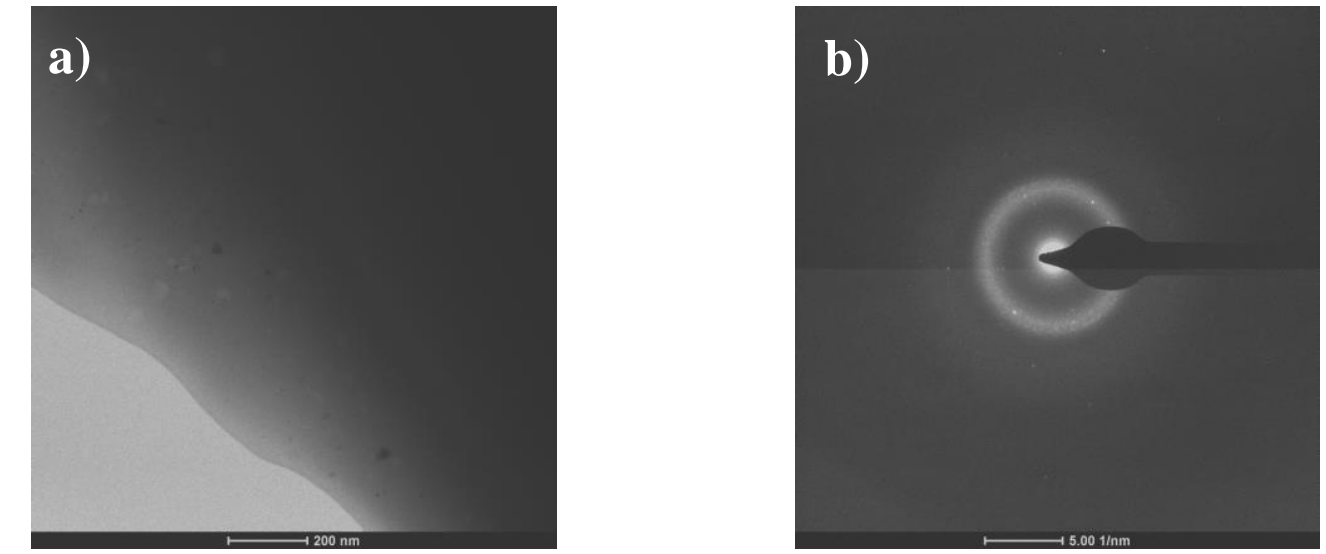

Fig. $9 \mathrm{Cu}_{49} \mathrm{Zr}_{45} \mathrm{Al}_{6}$ after $15 \mathrm{~h}$ of milling a) HR TEM image b) Electron diffraction pattern

\section{Conclusions}

$\mathrm{Cu}_{49} \mathrm{Zr}_{45} \mathrm{Al}_{6}$ and $\left(\mathrm{Cu}_{49} \mathrm{Zr}_{45} \mathrm{Al}_{6}\right)_{95} \mathrm{Ni}_{5}$ alloys were investigated. After identification of the initial phases, ball-milling process was performed. After $5 \mathrm{~h}$ of milling, 85 vol.\% of the structure transformed to amorphous. Based on the XRD results of both samples studied in this work, 15 hours were selected as adequate milling time to achieve a fully amorphous powder. TEM analysis confirmed the presence of nanocrystalline crystals in the amorphous matrix. Further milling, new $\mathrm{CuZr}$ crystalline phases appeared in the amorphous matrix and their quantity increased slightly. By adding nickel, the characteristic temperatures shifted to higher values measured by DSC $\left(T_{x}, T_{p}\right)$. The value of $\Delta T_{x}$ being equal to 64 implies a comparatively high glass forming ability, which slightly reduces by $\mathrm{Ni}$ addition to the $\mathrm{CuZrAl}$ alloy.

\section{Acknowledgement}

This work has been carried out as part of the TÁMOP 4.2.4.A/2-11-1-2012-0001 project within the framework of the New Hungarian Development Plan. The realization of this project is supported by the European Union, co-financed by the European Social Fund.

\section{References}

[1] D.M. Lee, J.H. Sun, D.H. Kang, S.Y. Shin, G. Welsch, C.H. Lee, A deep eutectic point in quaternary $\mathrm{Zr}-\mathrm{Ti}-\mathrm{Ni}-\mathrm{Cu}$ system and bulk metallic glass formation near eutectic point, Intermetallics, 21 (2012) 67-74.

[2] Y.F. Sun, H. Fujii, N. Tsuji, Y. Todaka, M. Umemoto, Fabrication of ZrAlNiCu bulk metallic glass composites containing pure copper particles by high-pressure torsion, J. Alloys Compd. 492 (2010) 149-152.

[3] H.S. Wang, Y.Z. Su, J. S.C. Jang, H.G. Chen, A comparison of crystallization behaviors of laser spot welded $\mathrm{Zr}-\mathrm{Cu}-\mathrm{Ag}-\mathrm{Al}$ and $\mathrm{Zr}-\mathrm{Cu}-\mathrm{Ni}-\mathrm{Al}$ bulk metallic glasses, Mat. Chem. Phys. 139 (2013) 215-219.

[4] M. Yan, J. Zou, J. Shen, Cooling rate effects on the microstructure and phase formation in Zr51Cu20.7Ni12Al16.3 bulk metallic glass, Sci. Tech. Adv. Mat. 7 (2006) 806-811 
[5] L.P. Déo, M.A.B. Mendes, A.M.S. Costa, N.D. Campos Neto, M.F. de Oliveira, Applying a new criterion to predict glass forming alloys in the $\mathrm{Zr}-\mathrm{Ni}-\mathrm{Cu}$ ternary system, Journal of Alloys and Compounds 553 (2013) 212-215

[6] H. Shao, Y. Xu, B. Shi, C. Yu, H. Hahn, H. Gleiter, J. Li, High density of shear bands and enhanced free volume induced in $\mathrm{Zr70Cu} 20 \mathrm{Ni} 10$ metallic glass by high-energy ball milling, Journal of Alloys and Compounds 548 (2013) 77-81

[7] J. Dutkiewicz, L. Jaworska, W. Maziarz, T. Czeppe, M. Lejkowska, M. Kubícek, M. Pastrnák, Consoldiation of amorphous ball-milled $\mathrm{Zr}-\mathrm{Cu}-\mathrm{Al}$ and $\mathrm{Zr}-\mathrm{Ni}-\mathrm{Ti}-\mathrm{Cu}$ powders, J. Alloys Compd. 434-435 (2007) 333-335

[8] H. Kishimura, H. Matsumoto, Fabrication of Ti-Cu-Ni-Al amorphous alloys by mechanical alloying and mechanical milling, J. Alloys Compd. 509 (2011) 4386-4389

[9] J. Bhatt, B.S. Murty, On the conditions for the synthesis of bulk metallic glasses by mechanical alloying, J. Alloys Compd. 459 (2008) 135-141

[10] D. Oleszak, T. Kulik, Influence of Sn Addition on the Amorphization and Thermal Stability of CuTiZrNi Powders Processed by Mechanical Alloying, Mater. Sci. Forum 636-637 (2010) 917-921

[11] C. Suryanarayana, Mechanical alloying and milling, Prog. Mat. Sci. 46 (2001) 1-184

[12] M.E. Siegrist, M. Siegfried, J.F. Löffler, High-purity amorphous Zr52.5Cu17.9Ni14.6A110Ti5 powders via mechanical amorphization of crystalline pre-alloys, Mater. Sci. Eng. A 418 (2006) 236-240

[13] Y.H. Zhao, Thermodynamic model for solid-state amorphization of pure elements by mechanical-milling, J. Non-Cryst. Solids 352 (2006) 5578-5585

[14] M. Seidel, J. Eckert, H.D. Bauer, L. Schultz, Mechanical Alloyed Zr-Based Metallic Glasses with Significant Supercooled Liquid Region, Mat. Sci. Forum 225-227 (1996) 119-124

[15] Z. Bian, G.L. Chen, G. He, X.D. Hui, Microstructure and ductile-brittle transition of as-cast Zrbased bulk glass alloys under compressive testing Mater. Sci. Eng. A 316 (2001) 135-144

[16] K. Tomolya, D. Janovszky, T. Janvari, A. Sycheva, F. Tranta, J. Solyom, T. Ferenczi, A. Roosz, Consolidation of Cu58Zr42 amorphous/nanocrystalline powders by PM, J. Alloys Compd. 536 (2012) S154-S158

[17] G. Körösy, K. Tomolya, D. Janovszky, J. Sólyom, Evaluation of XRD analysis of amorphous alloys, Mater. Sci. Forum 729 (2013) 419-423

[18] G.S. Firstov, Yu.N. Koval, A.N. Timoshevskii, J. Van Humbeeck, Dopov. Nats. Akad. Nauk. Ukr. (2010) 103-109 (ICSD\#: 167595)

[19] R. Meyer zu Reckendorf, P.C. Schmidt, A. Weiss, Reaction of Hydrogen with the HeuslerType Phases Cu2TiAl and Cu2ZrAl, Zeitschrift für Physikalische Chemie 163 (1989) 103-108 (ICSD\#: 656062)

[20] Y, Yokoyama, H. Inoue, K. Fukaura, A. Inoue, Relationship between the liquidus surface and the structure of $\mathrm{Zr}-\mathrm{Cu}-\mathrm{Al}$ bulk amorphous alloys, Mat. Trans. 43 (2002) 575-579 